\title{
Large fire initially reduces bird diversity in Poland's largest wetland biodiversity hotspot
}

\author{
Michał Walesiak $^{1}$ (D) Grzegorz Mikusiński ${ }^{2,3}$ (D) Z Zbigniew Borowski ${ }^{4}$. \\ Michał Żmihorski ${ }^{1}$ (D)
}

Received: 15 July 2021 / Revised: 14 January 2022 / Accepted: 25 January 2022 /

Published online: 16 February 2022

(c) The Author(s) 2022

\begin{abstract}
Freshwater wetlands are widely recognized as biodiversity hotspots for many organisms, including birds. Climate change and the projected increased risk of wetland fires may pose a major threat to wetland biodiversity in the future. There is urgent need to assess short- and long-term effect of fires on avian biodiversity and to establish relevant management implications. We analysed the short-term (first 3 months after fire) effect of a large (5 $500 \mathrm{ha}$ ) spring wildfire on the community of breeding marshland birds in the best-preserved Polish local wetland biodiversity hotspot: Biebrza Valley. We compared the avian community structure and abundance of certain species before and after the fire on the 18 permanent transects located in both burned and unburned habitats. Within first breeding season post fire, fire significantly reduced pooled abundance and species richness of the whole bird community. Three bird species of special conservation concern (including aquatic warbler) temporarily disappeared from burned areas, and the numbers of 11 other species declined. In contrast, only 3 species benefited from the fire, none of which depended on marshes as their primary habitat. Although the reported strong initial fire effect is likely to fade away in subsequent years, its immediate detrimental effects on marshland birds should not be underestimated. We conclude that it is essential to temporarily provide the unburned adjacent refuge areas with additional protection and bird-friendly management and to focus on preventing further degradation of marshes to increase their resilience to fire.
\end{abstract}

Keywords Wildfire · Marshlands · Avian biodiversity · Biebrza Valley · Disturbance · Aquatic warbler

Communicated by Karen E. Hodges.

Michał Walesiak

mwalesiak@ibs.bialowieza.pl

Extended author information available on the last page of the article 


\section{Introduction}

Freshwater ecosystems, including wetlands, are widely recognized as biodiversity hotspots for both plants and animals (Dertien et al. 2020; Reid et al. 2019). Although they cover only $0.8 \%$ of the world's land area, they host nearly $6 \%$ of all described animal species, including $33 \%$ of all vertebrates (Dudgeon et al. 2006). However, their area continues to shrink at an alarming rate; since the beginning of the twentieth century, the global area of freshwater wetlands has declined by 64-71\% (Davidson 2014). In Europe, between 1970 and 2008 alone, the total area of natural wetlands declined by 50\% (Dixon et al. 2016). The condition of the remaining wetlands is deteriorating mainly due to further anthropogenic water level regulation, habitat degradation, water pollution and invasive species (Dudgeon et al. 2006). As a result, wetland-associated biodiversity is declining faster than ever worldwide (Reid et al. 2019). For example, 40\% of European freshwater fishes are threatened according to the IUCN (Reid et al. 2019) and over 50\% of wetland bird species in Europe are declining (BirdLife International 2017). Huge efforts are now being made to restore lost wetlands or create new ones to support threatened wetland biodiversity (Kačergytė et al. 2021; Szalkiewicz et al. 2018).

Recent predictive models show that wetland-associated biodiversity may face further changes and degradation under pressure of climate change (Reid et al. 2019). In temperate zones of Northern Hemisphere, predicted warming across all seasons is expected, among other factors, to increase the annual evapotranspiration to precipitation ratio (Č́žková et al. 2013), frequency of soil moisture droughts (Grillakis 2019) and reduce snow cover depth (Brown and Mote 2009), leading to increased vulnerability of wetlands to fire (Čížková et al. 2013; Kettridge et al. 2015; Turetsky et al. 2015). This impact is expected to strike central European wetlands with particular severity (Okruszko et al. 2011). Although fire regularly occurs in some wetland ecosystems, and may help to promote wetland-associated biodiversity (Kotze 2013; Martin and Kirkman 2009), the development of a new disturbance regime with higher fire frequency or severity may pose a threat on sensitive species or habitats, thus creating new challenges in wetland conservation.

With the expected increased impact of fires on freshwater wetland ecosystems, there is an urgent need to assess both short-term and long-term consequences on wetland birds. This topic is understudied in Europe (but see Méró et al. 2015) partly due to the low predictability of wildfires at local scales, so many studies lack reliable assessments of bird diversity prior to the fire event, making it difficult to disentangle fire effects from random environmental variability. This may lead to biased conclusions on the true fire effects (Smith 2002). Accuracy in assessing fire effects is crucial for building knowledge base for further wetland management, although temporal aspects need to be taken into account to clearly separate short-term effects, occurring early after fire event, from long-term consequences.

Birds, often being focal species in wetland conservation (e.g., Ramsar Convention), may be affected by fires in various, species-depending ways. Short-term fire effects are often attributed to fire-induced iterations of vegetation cover; For example, species preferring tall vegetation, like reedbeds, tussocks, shrubs or tall grass may lose their habitats due to fire (Curnutt et al. 1998; Isacch et al. 2004). In contrast, short-term reduction of vegetation biomass may provide suitable foraging grounds for species preferring short vegetation, like waders or geese (Mitchell et al. 2006; Vogl 1973). The effect of fire on birds of prey seems complex: short-term reduction of plant biomass and height due to fire may facilitate prey detection and availability (Barnard 1987) but also reduce prey densities (Sharp Bowman 
et al. 2017). In a longer term, fire may effectively slow down succession in wetlands, helping to maintain suitable habitat for wetland specialists (Conway et al. 2010), while for some species, long-term effects may even contradict short-term effects (Grzywaczewski et al. 2014). As a consequence, impact of fire on wetland birds often remains unclear and depends on time scale considered. Unfortunately, for many regions large-scale empirical evaluations of fire consequences for wetland birds are not available.

Biebrza Valley is recognized as largest, best-preserved Polish wetland and one of the largest wetlands in central and western Europe. It is an important breeding and migratory site for birds (ca. 270 species observed within its borders, Biebrza National Park 2021) and hosts $75 \%$ of the EU population (20\% of the global population) of the aquatic warbler Acrocephalus paludicola, the rarest migratory bird in Europe (Świętochowski et al. 2010). It is recognized as most important breeding site in central and western Europe for several other wetland birds (e.g. great snipe Gallinago media, corn crake Crex crex and spotted crake Porzana porzana) (Birdlife International 2017).

Here we evaluate the initial impact (i.e. observed within 3 months since the fire event) of large wildfire of spring 2020 (5500 ha; largest open landscape fire in Poland after World War II) on bird community in Biebrza Valley. We hypothesize that: (1) As fire immediately reduces vegetation structure and kills the shrubs (Conway et al. 2010), shortly after fire bird species preferring tall vegetation for nesting, foraging and as shelters will be negatively impacted. Importantly, we expect that many marshland species of high conservation concern may fall into this group. (2) Several bird species preferring short vegetation and open landscape structure for which shrubs encroachment and expansion of tall vegetation is a threat, will increase in number at burned sites immediately after the fire. 3) Bearing in mind the possible species-specific responses to fire, the composition of the whole marshdependent bird community will be markedly altered by the fire, but with little change, if any, in overall bird abundance and species richness.

\section{Materials and methods}

\section{Study site}

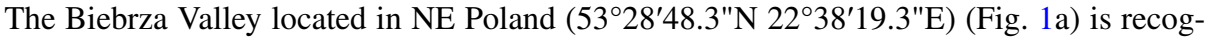
nized as best preserved large complex of fen marshes in western and central Europe (Żurek 2005). The valley covers 136900 ha, extending along the entire length (164 km) of Biebrza River. Roughly half of the area (66 800 ha) is protected as Biebrza National Park, the largest national park in Poland. It is recognized as a wetland of International Importance (Ramsar Convention Secretariat 2013) and Important Bird and Biodiversity Area (IBA, Birdlife International 2021).

Biebrza Valley was formed due to complex accumulation-erosion interactions during the last two Pleistocene glaciations and interglacials. Intensity and direction of those processes differed within the area, and three major units can be divided as a result: Upper Basin, Middle Basin and Lower Basin (Żurek 2005). Upper Basin is the most narrow part of Biebrza Valley (1.5 km wide) with total area of 12000 ha. Its bottom is covered with thick layer of peat (3-6 m) and gyttja (mud formed by partial peat decay) (Źurek 2005). Middle Basin is much wider $(20 \times 40 \mathrm{~km})$ and nearly rectangular in shape. Peat layer cover 45000 ha and reaches up to $3 \mathrm{~m}$ in depth (Dembek et al. 2005). Lower Basin is $12-15 \mathrm{~km}$ wide and it's formed mainly by one large fen with peat layer depth 


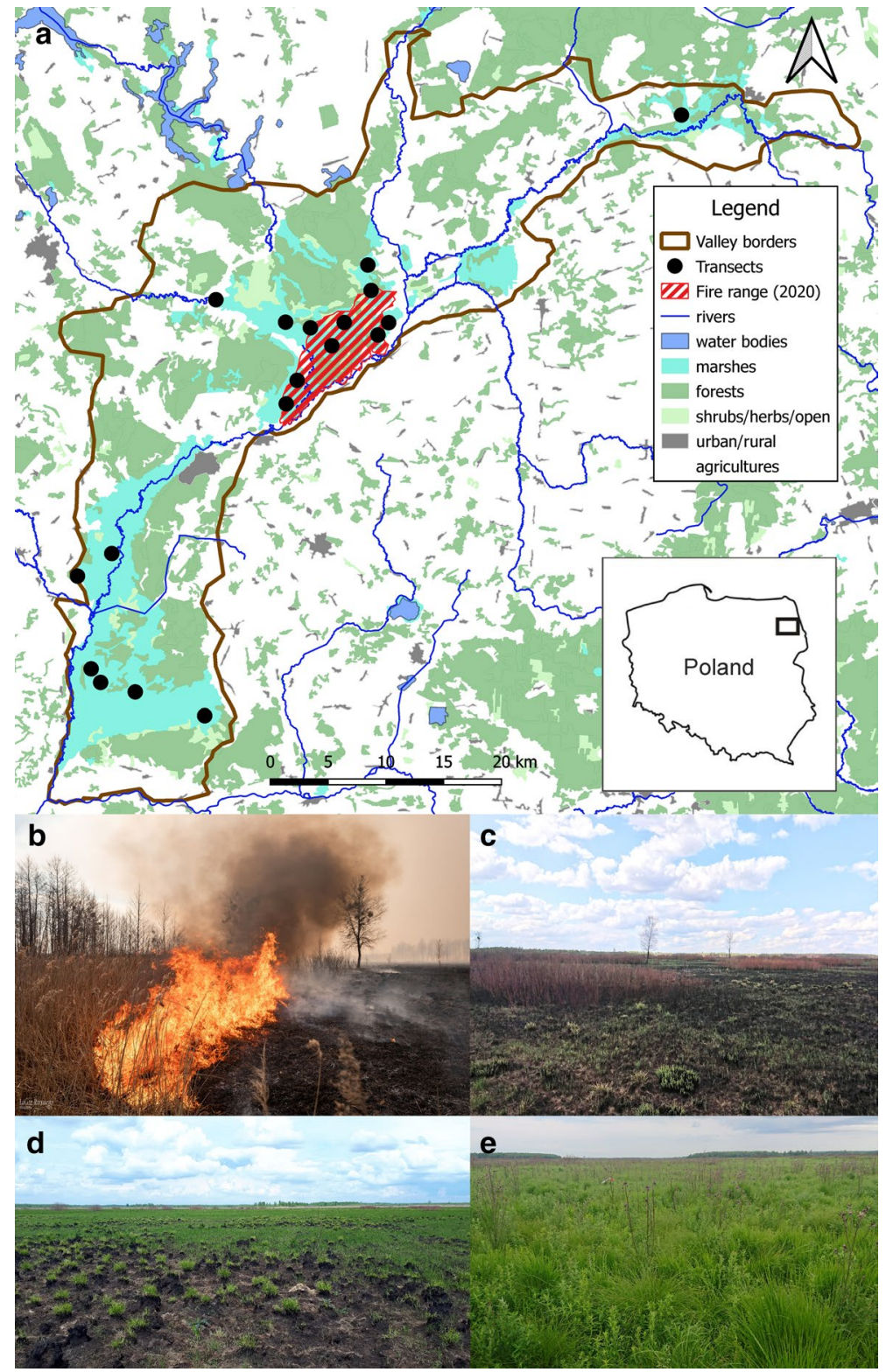

Fig. 1 Study site; a Location of fire and 18 bird count transects b Fire front (19th April) c Post-fire marsh landscape after 2 weeks (4th May) d Post-fire marsh landscape after 5 weeks (28th May) e Post-fire marsh landscape after 11 weeks (3rd July)

rarely exceeding $2 \mathrm{~m}$ (Dembek et al. 2005; Żurek 2005). Sand and gravel layer of average depth 5-15 m (20-30 m in Lower Basin) spans underneath the peat (Zurek 2005). Upper and Middle basins were subject to partial drainage due to human activity in the past, while Lower Basin was left largely undisturbed (Birdlife International 2021). 
The valley covers a mosaic of landscapes, with marshes and non-agricultural open areas occupying ca. 30\% of the area (Świętochowski et al. 2010). Large parts of Biebrza Valley consist of regularly flooded bogs and wet meadows dominated by sedge (Carex spp.) and oxbow lakes covered with reed (Phragmites australis). Unflooded areas consist mainly of pine (Pinus sylvestris), alder (Alnus spp.), willow (Salix spp.), and mixed forests, as well as sedge beds, bogs, pastures and meadows (Birdlife International 2021). Sedge, sedge moss, and reed peat soils cover majority of the valley, with numerous elevated moraine islands of loamy sand and gravel spread throughout the area. The valley is sparsely populated and agriculture (mostly extensive in character) has been largely abandoned in recent decades, resulting in scrub encroachment in many parts of the valley (Dembek et al. 2005). Some habitat management (mowing) has been introduced as conservation measures (Lachmann et al. 2010).

Natural fires were present in Biebrza Valley prior to human settlement, helping to shape vegetation of the valley's peatlands. However, in recent decades fires started to be perceived as one of the major threats to Biebrza Valley's ecosystems, because of their increasing frequency and area covered (Dembek et al. 2005). Recent yearly number of fires in the valley vary greatly depending on seasonal weather conditions: Between 2015 and 2019 there were 55 fires in total, which covered total area of 765 ha (Rutkowski et al. 2021). Prior to 2020, largest single fire occurred in 2002 and covered ca. 1200 ha (Kania et al. 2006). Majority of the fires in the region are humancaused and occur during winter-spring period due to illegal burning (Szczygieł et al. 2021). Valley is constantly monitored for the presence of fires with the use of terrestrial patrols and video cameras. Wherever possible, fires are extinguished as soon as detected by State \& Voluntary Fire Services, State Forests and Biebrza National Park (Rutkowski et al. 2021). Among other local threats to biodiversity, the most important is decline in groundwater levels (due to dredging, channelization, and water management), followed by the succession of expansive plant species (Ramsar Convention Secretariat 2013; Świętochowski et al. 2010).

\section{Fire of 2020}

During April 19-26, 2020, a large human-caused wildfire occurred over an area of 5500 ha (4\% of the total area) in the central part of Biebrza Valley (Fig. 1a). It was the largest open landscape fire in Poland after World War II (Szczygieł et al. 2021). Before the fire, the water level in the valley was extremely low, marking the lowest April water level in the Biebrza River in last 20 years (Institute of Meteorology and Water Management, Poland). Majority of the burned area consisted of marshlands. As a result of the fire, more than $90 \%$ of the surface vegetation (mainly dead biomass of reeds, tussocks and grasses from the previous year, but also shrubs and small trees) was burned and the area became significantly less covered with tall vegetation (Fig. 1b). Soon after the fire, surface vegetation began to re-sprout; At the beginning of May (ca. two weeks after the fire - Fig. 1c) vegetation was still scarce and there was observable difference between burned and control areas (mean NDVI values $0.25 \pm 0.05$ SD vs. $0.46 \pm 0.17$ SD, respectively) (Durka 2020). The green cover fully recovered within two months (Fig. 1d-e); Observed NDVI differences virtually disappeared by 8th June (burned vs. control $0.59 \pm 0.11$ vs. $0.60 \pm 0.13$ ) (Durka 2020). 


\section{Breeding bird counts}

Systematic bird counts took place in the area in 2015-2016 (i.e. 5 years before the fire) and 18 line transects were established throughout the Biebrza Valley's marshlands to cover the most important breeding sites of birds (Fig. 1a). Each transect consisted of two parallel lines (each $1 \mathrm{~km}$ long) divided into five sections ( $200 \mathrm{~m}$ long, 10 sections per transect). The minimum distance between transect centers was $1.4 \mathrm{~km}$ ( $4.2 \mathrm{~km}$ on average), while the distance between sections of the nearest adjacent transects was always greater than $600 \mathrm{~m}$. The 2020 fire affected the area containing six full transects, and one half of an additional transect (Fig. 1a). All other transects remained intact, providing controls for the fire effect.

Bird abundance data were collected during slow walks at a constant pace along transects (hereafter each such walk is referred to as a "survey"), following Gregory et al. (2004). Surveys were conducted nine times in each transect: three times per breeding season (1-15 May, 20-31 May, 5-21 June), in three years (2015, 2016, 2020). Each survey lasted approximately $1.5 \mathrm{~h}$ between 4 and $9 \mathrm{am}$, on days with good visibility and no or light rain. During each survey, birds were counted within hearing/seeing distance. Surveys were conducted by the same team of experienced ornithologists for all survey periods. The three surveys for each transect in given year were often done by two or more ornithologists. The final abundance of each species in a given transect section and year was considered, for this study, to be maximum abundance from the three surveys, and this value was used in all further statistical analyses.

In this study, we focused on marshland birds defined as species that typically inhabit wet meadows, pastures, tussock-covered marshes, reedbeds and shrubs (according to Kuczyński and Chylarecki 2012; Sikora et al. 2007). This group was chosen for analysis as it is of highest conservation concern and the target of most conservation efforts aimed at bird protection in the area. Species typical for other habitats, such as woodlands (woodpeckers, tits, treecreepers), urban areas (martins, swallows, swifts) and open water (ducks, swans, geese, grebes, terns and gulls) were excluded from the analysis. We also excluded some raptors that have very large territories or mainly hunting in flight (white-tailed eagle Haliaeetus albicilla, hobby Falco subbuteo), but left harriers (Circus spp.), common buzzard Buteo buteo and eurasian kestrel Falco tinnunculus. Bird flocks larger than 50 individuals (Eurasian Starling Sturnus vulgaris, Northern Lapwing Vanellus vanellus) were also excluded as largely migrating. A total of 63 species were included (hereafter called "marshland birds"), while 62 were excluded from further analysis (see Appendix Tables 1-2 for details).

Using data on 63 marshland bird species, six indices of bird diversity were calculated for each transect section and year: abundance and richness of all species, abundance and richness of "Species of European Conservation Concern" (SPECs; Birdlife International 2017), and abundance and richness of species included in Polish Red List of Birds, listing rare or quickly declining species in Poland (red-listed; Wilk et al. 2020).

\section{BACl study design}

Each data record (i.e., abundance of each species in a single transect section in a given year) was attributed to one of two time periods (before vs after the fire) and one of two treatments (fire vs no fire). Such approach, known as before-after control-impact study design (BACI), allowed us to disentangle the fire effect from a natural temporal and spatial variation of a biological response driven by factors other than the treatment of interest 
(Smith 2002). Following the design, our records were therefore divided into four groups: before-control (BC), before-impact (BI), after-control (AC), after-impact (AI), hereafter referred to as the "BACI groups".

\section{Statistical analysis: GAMMs, logistic regression and indicator species analysis}

For all bird species with abundance $\geq 15$ individuals (i.e. 47 species; in case of remaining 16 species generated models exceeded maximum number of iterations), generalized additive mixed models (GAMM) in "mgcv" package (Wood 2017) in R (version 4.1.0, R. Core Team 2013) were fitted. GAMMs were chosen as they allow to fit random effects as penalized regression terms, which are faster to compute and more reliable than conventional random effects in general mixed models (Wood 2017). In each GAMM, species abundance was a response variable and three explanatory variables were considered: period (before vs after fire), treatment (fire vs no fire) and interaction of these two, the latter being a formal test of the fire effect. Also, random effects of year, transect and section were included to account for spatial and temporal dependency of the data, and were fitted with ridge penalty splines (Wood 2017). All 47 GAMMs were fitted using negative binomial distribution and logarithmic link with theta dispersion parameter estimated directly from data. This approach was preferred over Poisson distribution, because of overdispersion observed in most species (variance to mean ratio, White and Bennetts 1996). We reported "positive short-term fire effect" on a species if period/treatment interaction coefficient had value above 0 with associated $\mathrm{p}<0.05$ and "negative short-term fire effect" for coefficients below $0(\mathrm{p}<0.05)$.

Seven species were absent in one of four BACI groups (specifically: after-impact, see Appendix Table 3 for details), resulting in a problem of perfect data separation. As a result, confidence intervals of model coefficients were impossible to estimate using standard maximum likelihood methods (GAMM) (Heinze 2006). Hence, to obtain interpretable results for those seven species, logistic regression models were performed instead of GAMMs (Firth; see Appendix Table 4 for details). Species occurrence (i.e. abundance transformed to presence/absence binomial values) was used as a response variable, while period, treatment, their interaction and transect as explanatory variables. The coefficient was obtained using penalized maximum likelihood method (Firth 1993) in "logisft" package (Heinze et al. 2020) in R.

Another six GAMMs were performed to analyse how six diversity indices (i.e., abundance and species richness of all marshland bird species, SPEC species and red-listed species) changed in response to fire. Here we followed the procedure described above for species-specific GAMMs.

Spatial autocorrelation of residuals of the models was checked with spline correlograms using "ncf" package (Bjornstad 2020) in R. As in no case we did record significant spatial autocorrelation of the residuals and in all cases correlation never exceeded 0.1 we assume the models meet the criteria of spatial independency of data. Predicted values and confidence intervals from the models were plotted using ggplot2, ggeffects (GAMMs) and DAMisc (logistic regressions) packages (Armstrong 2021; Lüdecke 2018; Wickham 2016) in $\mathrm{R}$.

In addition to GAMM and logistic regression models, we performed two Indicator Species Analyses using "indicspecies" package in R (9999 permutations, De Cáceres and Legendre 2009). We compared separately after-impact group with before-impact group (AI vs $\mathrm{BI}$; same area before and after the fire) and after-control with after-impact group (AC vs 
Fig. 2 Short-term impact of fire on bird community in Biebrza Valley, NE Poland; Effect size, meant as model coefficient of interaction between period (before vs after) and impact of wildfire (fire vs control) as found by GAMM/Firth's logistic regression models, was presented for: a 47 marshland bird species (abundance $\geq 15$ ), b diversity indices for all 63 marshland bird species. Additional diversity indices were calculated for those belonging to Species of Special European Conservation Concern according to Birdlife International 2017 (SPEC, $\mathrm{n}=31$ ) and species present on Polish Red List of Birds according to Wilk et al. 2020 (red-listed, $n=18$ ). Horizontal bars represent $95 \%$ confidence intervals. Significance level of fire effect was presented for each species $(* * \mathrm{p}<0.01 ; * \mathrm{p}<0.05)$. Trophic guilds were attributed following Pigot et al. (2020). Further details provided in Appendix Tables 3, 4.

AI; same period of time, control and burned areas). We used threshold of $p<0.05$ to determine indicator species for both categories in each of the two analyses.

\section{Statistical analysis: MANOVA, PCA}

To analyse differences in bird communities between BACI groups, Permutational Analysis of Variance (PERMANOVA) was performed. Differences in bird abundances were transformed into Bray-Curtis dissimilarity matrix in "vegan" $\mathrm{R}$ package. To make the number of records the same for before and after time periods, data records from 2015 to 2016 (i.e., both years before the fire) were averaged. Bird community compositions of four BACI groups were compared using PERMANOVA on two levels: transect and section. Prior to transect level analysis, section abundances were averaged in each transect separately for before and after time periods.

Next, multivariate homogeneity of groups dispersions (PERMDISP2) test was performed to check for homogeneity of variances between treatment groups (Anderson 2006; Oksanen et al. 2020). Permutational MANOVA (9999 permutations) and Pairwise Permutational MANOVA with Bonferroni p-value correction (9999 permutations) were used on each dissimilarity matrices to statistically test differences in species composition among BACI groups (Anderson 2001; Martinez Arbizu 2020).

To visualize differences in bird communities detected with PERMANOVA, principal component analysis (PCA) was performed based on scaled, Hellinger-transformed species data (Oksanen et al. 2020).

\section{Results}

A total of 9786 marshland bird observations were recorded. The five most common species were as follows: sedge warbler Acrocephalus schoenobaenus $(\mathrm{n}=1234)$, common reed bunting Emberiza schoeniclus (1072), common snipe Gallinago gallinago (821), meadow pipit (791) and willow warbler Phylloscopus trochilus (572). Mean bird abundance on a section was $18.1(\mathrm{SD}=6.85)$ and mean species richness was $9.46(\mathrm{SD}=3.03) .31$ out of 63 marshland birds were included in list of European Birds of Conservation Concern SPEC (six of which are globally threatened) and 18 species in Polish Red List of Birds (four with "Critically Endangered" status).

\section{Species-level short-term response to fire}

Fire turned out to be important (statistically significant interaction between period and treatment was recorded) for abundance of 17 species among 47 tested, having short-term 
a

\author{
Alauda arvensis** \\ Coturnix coturnix \\ Corvus corax \\ Anthus trivialis* \\ Lyrurus tetrix \\ Limosa limosa \\ Upupa epops \\ Corvus cornix \\ Lanius excubitor \\ Vanellus vanellus \\ Tringa totanus \\ Acrocephalus palustris \\ Phasianus colchicus \\ Emberiza citrinella \\ Luscinia luscinia \\ Tringa glareola \\ Sylvia curruca \\ Anthus pratensis ** \\ Cyanecula svecica \\ Turdus pilaris \\ Phylloscopus trochilus \\ Cuculus canorus
}

Conservation status

present on neither list

included on Polish Red List of Birds (red-listed)

Species of European Conservation Concern (SPEC)

present on both lists (SPEC + red-listed)

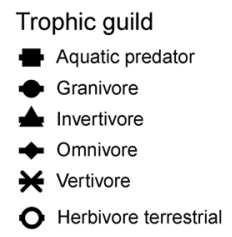

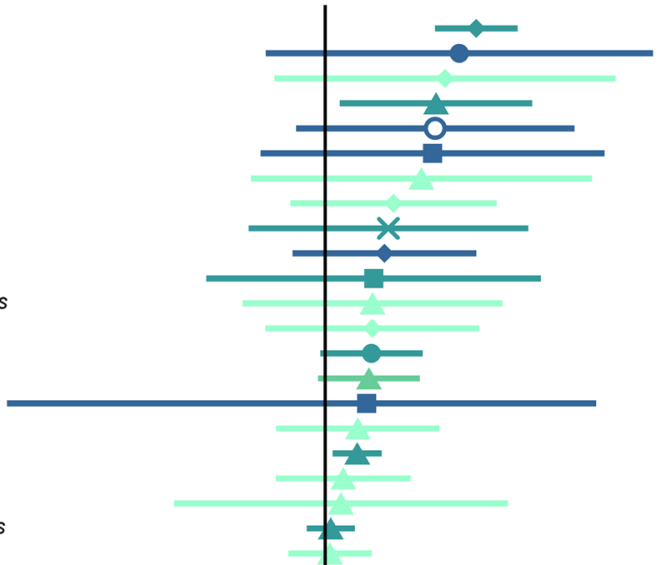

Sturnus vulgaris Emberiza schoeniclus* Sylvia communis Grus grus Sylvia nisoria

Acrocephalus schoenobaenus ** Hippolais icterina

Carpodacus erythrinus* Pica pica

Gallinago gallinago*

Motacilla citreola

Saxicola rubetra**

Locustella fluviatilis

Lanius collurio**

Buteo buteo

Circus pygargus**

Locustella naevia**

Circus aeruginosus*

Acrocephalus arundinaceus Locustella luscinioides**

Crex crex*

Gallinago media

Acrocephalus scirpaceus**

Asio flammeus ** Acrocephalus paludicola**

$-10$

$-5$

Conservation status

b

present on neither list

included on Polish Red List of Birds (red-listed)

Species of European Conservation Concern (SPEC)

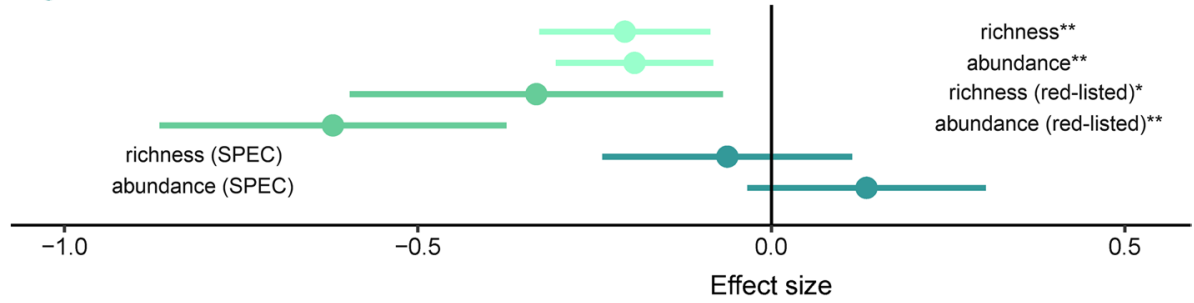

positive effect on three species and negative on 14 (Figs. 2a, 3). All three species positively affected by the fire were species of European conservation concern (included on SPEC list), while among 14 negatively affected species, five were included on both lists (SPEC and Polish Red List of Birds), one only on Polish Red List of Birds and two only on SPEC. 


\section{Negative response}
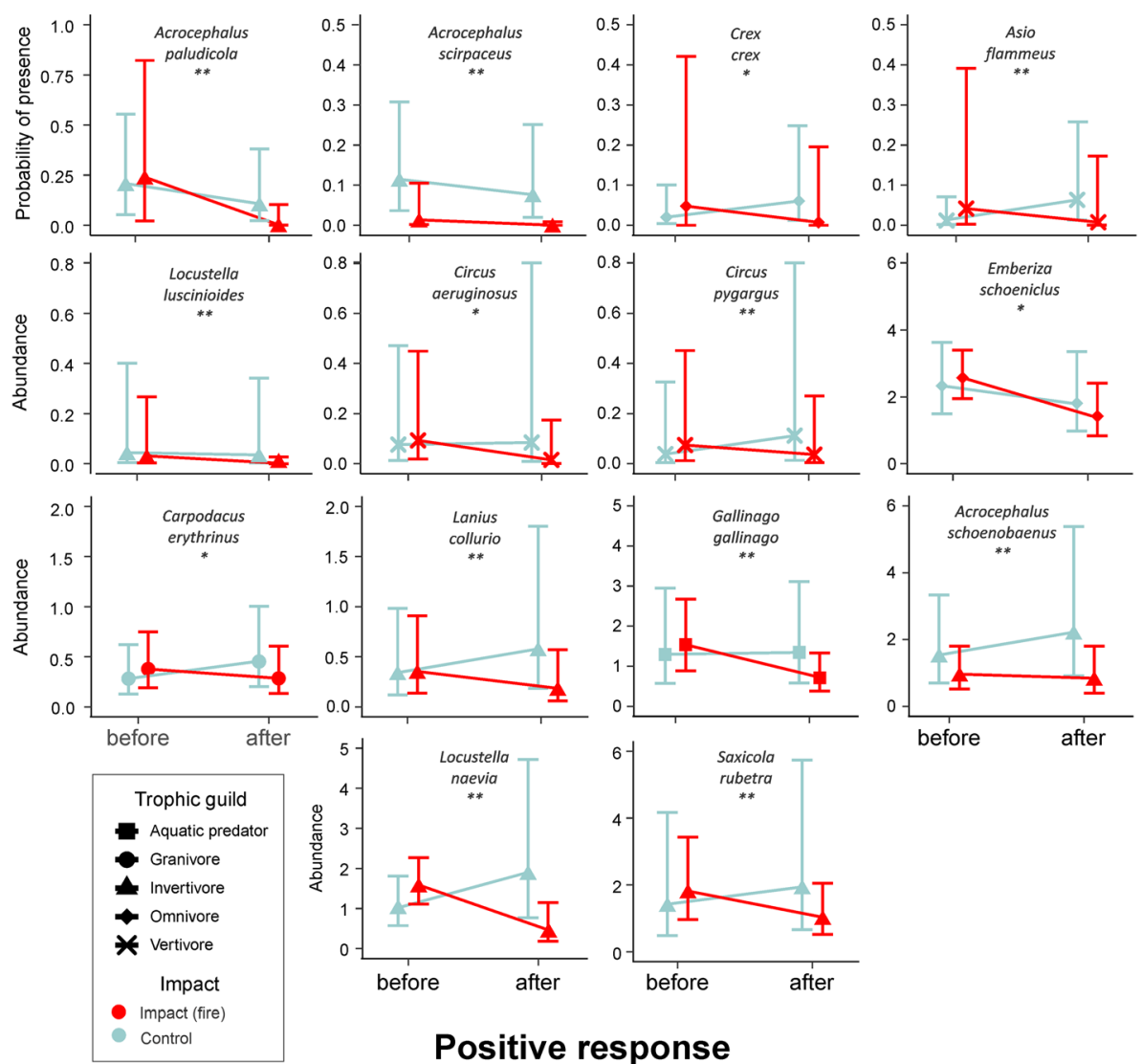

\section{Positive response}
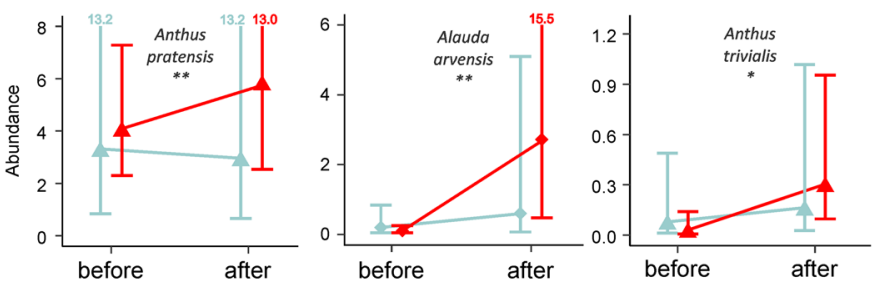

Fig. 3 Short-term impact of fire on bird community in Biebrza Valley, NE Poland; Abundance (GAMM models) and probability of presence (Firth logistic regression models), of marshland birds significantly $(\mathrm{p}<0.05)$ impacted by fire in relation to time (before vs after fire) and impact (fire vs control), as predicted by models described in Fig. 2 and Appendix Table 4. Vertical bars represent 95\% confidence intervals. In cases, where upper confidence intervals exceeded scale, they were shown on the graphs as numbers. Significance level of fire effect was presented for each species $\left(* * \mathrm{p}<0.01 ;{ }^{*} \mathrm{p}<0.05\right)$. Trophic guilds were attributed following Pigot et al. (2020)

Four of the negatively affected species temporarily disappeared from burned areas after the fire (aquatic warbler, short-eared owl Asio flammeus, corn crake and reed warbler Acrocephalus scirpaceus; see Appendix Table 3 for details). 
We identified 12 indicator species for fire treatment, with five species common for both performed analysis (BI vs. AI \& AC vs. AI) (Table 1a, b). In both cases, Eurasian skylark (Alauda arvensis) was best indicator species for fire (Indicator value $>0.75$ ). We identified 10 species being indicators of control areas (i.e. no fire), with six species common for both analysis. Indicator species detected for control areas slightly differed between two performed analysis, with common snipe and common grasshopper warbler (Locustella naevia) among best indicator species for both.

\section{Community-level short-term response to fire}

Fire immediately altered the abundance and richness of studied bird assemblage (Fig. 2b, Fig. 4). The total abundance of all 63 marshland species remained constant after the fire on impact areas (difference $=0.03$ ), but at the same time increased by 4.43 individuals on control sites (Fig. 4). Fire caused decline of species richness by 0.3 species/section, while

Table 1 Significant $(\mathrm{p}<0.05)$ indicator species for fire and control areas compared within same space, but different time period (a. before/impact vs. after/impact) and different space, but same time period (b. after/ control vs after/impact)

\begin{tabular}{|c|c|c|c|c|c|}
\hline \multicolumn{6}{|l|}{ Before/fire vs after/fire } \\
\hline \multicolumn{3}{|l|}{ Treatment $=$ Before/fire } & \multicolumn{3}{|l|}{ Treatment $=$ After $/$ fire } \\
\hline Species & Indicator value & $\mathrm{p}$ value & Species & Indicator value & $\mathrm{p}$ value \\
\hline Emberiza schoeniclus & 0.78 & 0.000 & Alauda arvensis & 0.90 & 0.000 \\
\hline Gallinago gallinago & 0.74 & 0.000 & Phylloscopus trochilus & 0.61 & 0.047 \\
\hline Locustella naevia & 0.71 & 0.000 & Anthus pratensis & 0.60 & 0.013 \\
\hline Locustella luscinioides & 0.61 & 0.000 & Luscinia luscinia & 0.51 & 0.000 \\
\hline Saxicola rubetra & 0.60 & 0.021 & Anthus trivialis & 0.43 & 0.000 \\
\hline Acrocephalus paludicola & 0.56 & 0.000 & Emberiza citrinella & 0.42 & 0.006 \\
\hline Acrocephalus scirpaceus & 0.38 & 0.003 & Phasianus colchicus & 0.38 & 0.009 \\
\hline \multirow[t]{4}{*}{ Circus aeruginosus } & 0.37 & 0.013 & Coturnix coturnix & 0.36 & 0.000 \\
\hline & & & Corvus cornix & 0.34 & 0.003 \\
\hline & & & Lanius excubitor & 0.33 & 0.003 \\
\hline & & & Lyrurus tetrix & 0.29 & 0.048 \\
\hline \multicolumn{6}{|l|}{ After/no fire vs after/fire } \\
\hline \multicolumn{3}{|l|}{ Treatment $=$ After $/$ no fire } & \multicolumn{3}{|l|}{ Treatment $=$ After/fire } \\
\hline Species & Indicator value & $\mathrm{p}$ value & Species & Indicator value & $\mathrm{p}$ value \\
\hline Locustella naevia & 0.71 & 0.000 & Alauda arvensis & 0.79 & 0.000 \\
\hline Gallinago gallinago & 0.67 & 0.001 & Anthus pratensis & 0.62 & 0.012 \\
\hline Saxicola rubetra & 0.60 & 0.013 & Phasianus colchicus & 0.41 & 0.000 \\
\hline Locustella luscinioides & 0.53 & 0.000 & Cyanecula svecica & 0.37 & 0.048 \\
\hline Lanius collurio & 0.52 & 0.007 & Coturnix coturnix & 0.34 & 0.004 \\
\hline Acrocephalus paludicola & 0.44 & 0.001 & Lyrurus tetrix & 0.30 & 0.003 \\
\hline Circus aeruginosus & 0.40 & 0.006 & & & \\
\hline Circus pygargus & 0.38 & 0.041 & & & \\
\hline
\end{tabular}


Fig. 4 Short-term impact of fire on bird community in Biebrza Valley, NE Poland; Diversity indices of all 63 marshland birds in relation to time (before vs after) and impact (fire vs control) as predicted by models described in Fig. $2 b$ and Appendix Table 4. Only diversity indices, which were significantly affected by fire $(\mathrm{p}<0.05)$, are shown. Significance level of fire effect was presented for each index $(* * \mathrm{p}<0.01 ; * \mathrm{p}<0.05)$. Vertical bars represent $95 \%$ confidence intervals

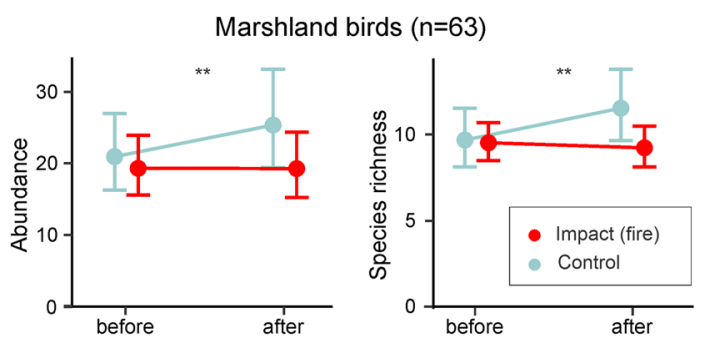

Species included in Polish Red List of Birds $(n=18)$

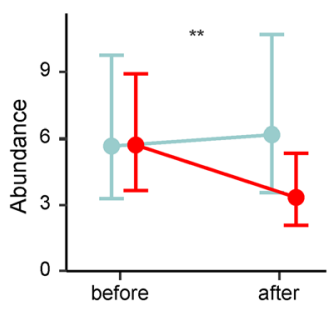

on control areas richness increased by 1.86 species/section. Similar trend was observed for red-listed species, in which abundance and richness increased in control areas (by 0.51 and 0.09 respectively) and decreased in impact areas (by 2.37 and 0.68 respectively). Abundance and richness of SPEC species did not change due to fire (Fig. 2b).

Permutational MANOVA showed a separation of bird community recorded at burned sites shortly after fire as compared to remaining BACI groups. However, as homogeneity of variance test among BACI groups confirmed violation at the level of sections $(\mathrm{F}=17.5$, $\mathrm{p}<0.001$ ), we restricted PERMANOVA analysis to data at the level of transects (homogeneity test results, $\mathrm{F}=1.57, \mathrm{p}=0.21$ ). Bird assemblages of BACI groups significantly differed from each other (PERMANOVA, $\mathrm{F}=1.75$, $\mathrm{p}<0.05$; Fig. 5a). This difference, however, resulted solely from the difference between BI and AI (pairwise PERMANOVA, $\mathrm{F}=2.98, \mathrm{p}<0.05$ ) and there was no significant difference between any other pair of BACI groups. We show visual separation of those two significantly different BACI groups (before-fire and after-fire) using PCA (Fig. 5a-b).

\section{Discussion}

Our study clearly demonstrated that - partly contradicting our hypothesis - large wildfire substantially reduced diversity of marshland birds in burned area of Biebrza Valley in first weeks after the fire event. This effect was observed both in the overall abundance and species richness of marshland birds and at the species level, including abundances of species of high conservation concern. Only a few species benefited from the fire, but none of them inhabits marshlands as its primary habitat (Kuczyński and Chylarecki 2012). These results are in general consistent with the observed short-term impact of wildfires (Heim et al. 2019) and prescribed fires (Hanowski et al. 1999; Méró et al. 2015) in temperate wetlands (but see Conway et al. 2010). Below, we discuss fire-induced mechanisms potentially leading to a short-term decline of marshland birds and their implications for wetland biodiversity conservation and management, as well as possible long-term effects. 

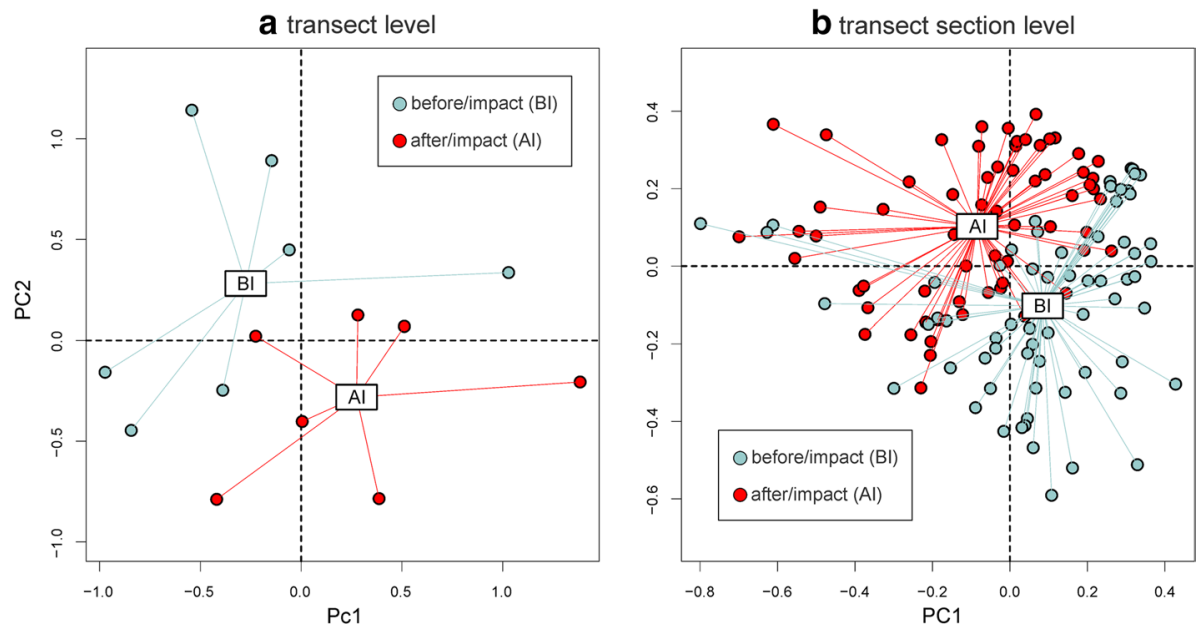

Fig. 5 Principal component analysis (PCA) performed on Hellinger-transformed marshland bird community matrix in two time periods: before and immediately after the fire. using transects (a) and single sections of transects (each transect $=10$ sections) (b). Fire-induced short-term alteration of the two bird communities (before-impact and after-impact) for which significant differences were confirmed (PERMANOVA $p<0.05$ ) were visualized. Presented PC1 and PC2 axes explain in total $37 \%$ of variance on the transect level (a) and $18 \%$ on the section level (b)

\section{Bird community—short-term response to fire}

As predicted, fire immediately benefited some bird species of open habitats that avoid tall vegetation. Two out of three positively affected species are generalists of open habitats and inhabit primarily cropland, including arable land (Eurasian skylark) and grassland (meadow pipit), while none relies on marshlands as their main habitat (Kuczyński and Chylarecki 2012). Several marshland species preferring short vegetation were observed on the study area, e.g. northern lapwing and godwit Limosa limosa (Żmihorski et al. 2018), but contrary to our hypothesis, they did not respond positively to fire. Also, none of typical marshland species were identified among indicator species for burned area.

In contrast, the numbers of several marshland bird specialists inhabiting tall vegetation, reeds and tussocks immediately declined, confirming our predictions. Temporary loss of suitable habitat structures negatively impacted reed passerines (sedge warbler, common reed bunting, common grasshopper warbler), open marshland passerines (aquatic warbler), and open marshland non-passerine birds (common snipe). Several marsh raptors also showed a negative response to fire (Montagu's harrier Circus pygargus, marsh harrier Circus aeruginosus, short-eared owl). Most of the above mentioned species were also identified as indicator species for control areas. Similar short-term patterns, although from slightly different ecosystems, were identified in wetlands of Argentina (Isacch et al. 2004) and eastern Russia (Heim et al. 2019), where the vast majority of wetland specialists declined after fire.

Short-term vegetation removal seems to be the main driver of observed initial decline of marshland birds, since most of the negatively impacted species rely on tall vegetation for foraging and breeding and short sward does not provide them with suitable habitats. In addition, gleaning arboreal species (dependent on tall vegetation for foraging; see 
Appendix Table 4 for details) were identified among roughly half of indicator species of control areas (e.g., common grasshopper warbler, Savi's warbler Locustella luscinioides).

As fire influences short-term food availability in variety of habitats (Panzer 2002; Sileshi and Mafongoya 2006; Vieira and Briani 2013), food base alteration could be another important driver of observed fire effect. In case of our study, insects started to occur at burned sites just a few days after the fire, and some groups (e.g., beetles Coleoptera) even increased in diversity in burned areas (Jaworski et al. in preparation), so the food base likely remained available for at least some insectivorous species. However, as invertebrates react to the fire in different species-dependent ways (García-Domínguez et al. 2010; Panzer 2002), the food availability for some insectivorous specialists could be temporarily reduced. The aquatic warbler, for example, is an insectivorous species that forages in low vegetation directly adjacent to higher vegetation and apparently benefits from the varied structure of its foraging habitat (Tanneberger et al. 2013). Fire may have temporarily simplified habitat structure to the point that it became incompatible for the species, contributing to the loss of this important species from burned areas.

At the same time, fire provided better access to bare soil as a foraging layer, as most of the dead biomass disappeared, thus improving invertebrate availability for some birds (Hoste-Danyłow et al. 2010). All three species that showed a positive response to fire in our analysis were mainly ground foragers (Appendix Table 4). In addition, ground foraging species formed majority of indicator species for burned areas, despite no confirmed positive fire effect on some of them (e.g., black grouse Lyrurus tetrix, common quail Coturnix coturnix, yellowhammer Emberiza citrinella, thrush nightingale Luscinia luscinia).

Contrary to invertebrates, fire caused an immediate decline in the density of small mammals, especially the disappearance of the most common rodent species in the valley-the root vole Microtus oeconomus (Borowski et al. in preparation). Rodents are a basic food item for all three birds of prey negatively affected by the fire-short-eared owl (Lesiński et al. 2016), montagu's harrier (Kitowski et al. 2021) and marsh harrier (Brzeziński and Żmihorski 2009). Since the availability of prey is one of the main factors influencing population densities and habitat use in birds of prey (Korpimäki and Norrdahl 1991; Newton 2007), the temporal absence of rodents could largely contribute to the observed short-term decline of these species on burned areas.

\section{Implications for conservation}

The impact of fire on wetland species of conservation concern is ambiguous and there is an ongoing debate if it should be recommended as a management tool (Conway et al. 2010; Hochkirch and Adorf 2007). In short term, fire may positively affect some species of high conservation concern, while causing declines in others (Conway et al. 2010; Heim et al. 2019; Isacch et al. 2004). In our study, fire negatively affected marshland bird specialists and led to temporary disappearance of four species (aquatic warbler, short-eared owl, corn crake and reed warbler). Some studies show similar short-term effects of fire on specialist species of high conservation concern in wetlands (Curnutt et al. 1998; Heim et al. 2019) and highlight the importance of unburned adjacent areas as refugia that allow survival and recolonization of burned areas by rare species (Grzywaczewski et al. 2014; Heim et al. 2019; Shaw et al. 2021). We therefore suggest that when fires occur, adjacent areas that have not burned could be temporarily covered with additional protection and bird-friendly management (e.g., delayed or reduced mowing). 
In contrast, several rare and/or currently declining species actually benefitted from the fire in short term (Eurasian skylark, meadow pipit, and largely similar trends observed for yellowhammer, thrush nightingale, common quail, northern lapwing, godwit and black grouse) (Chylarecki et al. 2018). It suggests that burned marshland patches may become important local habitats for these declining species. Therefore, we encourage to temporarily introduce bird-friendly protection measures (e.g. limited access for people) in burned marshes as well.

However, to establish general management implications it is crucial to take into consideration both short-term and long-lasting fire effects. In numerous studies, strong initial response of bird community was recorded during first year after fire, to virtually disappear after 3-4 years (Heim et al. 2019; Mérő et al. 2015; Newman et al. 2018). In addition, wetland species of highest conservation concern, negatively affected by fire during first year, often returned to pre-fire abundances (Yellow-breasted bunting Emberiza aureola in Heim et al. 2019) or even reported increase (Aquatic warbler in Grzywaczewski et al. 2014) already one year after the fire. In longer term, fire can help keep marshes open by stopping the encroachment of scrub and trees, benefiting wetland herbaceous vegetation and associated biodiversity (Kotze 2013; Martin and Kirkman 2009; O'Connor et al. 2020). Overgrowth of shrubs and trees in marshes is one of the greatest threats to marsh biodiversity (Čížková et al. 2013; Kotowski and Piórkowski 2005), also in Biebrza Valley (Dembek et al. 2005). For these reasons, introduction of fire as management tool is recommended in some wetland environments to protect marshland birds (Conway et al. 2010), even despite negative short-term effects on target species (Grzywaczewski et al. 2014). Therefore, the consequences of fires, even if initially negative, can be different and diverse in the long term and need to be monitored.

Predicted increased fire frequency due to climate change may shorten intervals between fires (change of fire regime) which permanently alters vegetation structure and thus pose a serious threat to related biodiversity, including birds (Chalmandrier et al. 2013; Gosper et al. 2019). Increased fire frequencies affect vegetation structure also in temperate wetlands (Heim et al. 2019) and are hypothesized to affect bird community in a longer scale. In addition, expected changes in fire regime may increase risk of peat layer ignition. In contrary to surface fires, peat fires permanently damage peat layers, causing permanent ecosystem changes (Filkov et al. 2015; Kettridge et al. 2015). They may facilitate scrub expansion on wetlands, posing major threat to wetland-specific biodiversity (Kettridge et al. 2015; Sulwiński et al. 2020).

Many marshland species of conservation concern may exist in the form of metapopulations, as suitable habitat patches are usually heavily fragmented and scattered over large areas, while individuals disperse among them (Żmihorski et al. 2016). Theory predicts that while large patches may serve as population sources, small ones are also important as "stepping stones" that enhance network connectivity and thus increase population survival (Hanski 1999). In such systems, species might find refuge in adjacent unburned patches and then recolonize the burned patches the next year when the fire effect subsides. However, climate change, along with water management, often leads to further drying of water-dependent ecosystems and can cause severe droughts and synchronized fires over large areas. The simultaneous burning of large areas can wipe out large metapopulation fragments and significantly reduce connectivity between patches, with dramatic consequences for rare marsh species. It is therefore critical to prevent further drainage of marshes, while restoring previous water levels and dynamics to increase their resilience to fire.

Supplementary Information The online version contains supplementary material available at https://doi. org/10.1007/s00300-022-03025-4. 
Acknowledgements The authors would like to thank Michał Białek, Szymon Cios, Szymon Czernek, Piotr Dębowski, Agnieszka Grajewska, Grzegorz Grygoruk, Radosław Kozik, Justyna Kubacka, Piotr Marczakiewicz, Paweł Mirski, Łukasz Mucha, Michał Sułecki, Rafał Szczęch, Piotr Świętochowski and Tomasz Tumiel for data collection and sharing valuable observations, Beata Głębocka and Joanna Zawadzka for help with hydrological data, Dave Armstrong for his guidance in creating logistic regression effect plots, Łukasz Rutkowski and Karolina Iwińska for sharing their photographs of study area and two anonymous reviewers for helping to improve the quality of the manuscript.

Author contributions MW: Methodology, Software, Validation, Formal Analysis, Writing Original Draft, Writing Review \& Editing, Visualization. GM-Conceptualization, Writing Original Draft, Writing Review \& Editing. ZB: Project Administration, Funding Acquisition, Writing Review \& Editing. MŻ: Conceptualization, Methodology, Validation, Writing Original Draft, Writing Review \& Editing, Supervision. All authors read and approved the final version of the manuscript.

Funding This work was supported by the Forest Fund from the State Forests under contract number EZ.0290.1.24.2020 with the Biebrza National Park.

Data availability The datasets generated during and/or analysed during the current study are not publicly available due to their possible future use in another article, but are available from the corresponding author on reasonable request.

Code availability The code generated during and/or analysed during the current study is not yet publicly available, but will be published in case the manuscript is accepted for publication.

\section{Declarations}

Conflict of interest The authors declare no competing interests.

Ethical approval Not applicable.

Informed consent All authors agreed to participate in the research and be a part of this manuscript.

Consent for publication All authors agree with the contents of the manuscript and its submission to the journal.

Open Access This article is licensed under a Creative Commons Attribution 4.0 International License, which permits use, sharing, adaptation, distribution and reproduction in any medium or format, as long as you give appropriate credit to the original author(s) and the source, provide a link to the Creative Commons licence, and indicate if changes were made. The images or other third party material in this article are included in the article's Creative Commons licence, unless indicated otherwise in a credit line to the material. If material is not included in the article's Creative Commons licence and your intended use is not permitted by statutory regulation or exceeds the permitted use, you will need to obtain permission directly from the copyright holder. To view a copy of this licence, visit http://creativecommons.org/licenses/by/4.0/.

\section{References}

Anderson MJ (2001) A new method for non-parametric multivariate analysis of variance. Austral Ecol 26:32-46. https://doi.org/10.1046/j.1442-9993.2001.01070.x

Anderson MJ (2006) Distance-based tests for homogeneity of multivariate dispersions. Biometrics 62:245253. https://doi.org/10.1111/j.1541-0420.2005.00440.x

Armstrong D, (2021) DAMisc: Dave Armstrong's Miscellaneous Functions. R package version 1.7.2

Barnard P (1987) Foraging site selection by three raptors in relation to grassland burning in a montane habitat. Afr J Ecol 25:35-45. https://doi.org/10.1111/j.1365-2028.1987.tb01088.x

Biebrza National Park (2021) List of birds observed at the Biebrza Valley [WWW Document]. URL https:// www.biebrza.org.pl/159, list-of-birds Accessed 26 February 21 
Birdlife International, 2017. European birds of conservation concern:populations, trends and national responsibilities [WWW Document]. URL https:/www.birdlife.org/sites/default/files/attachments/ European Birds of Conservation Concern_Low.pdf Accessed 22 June 21

BirdLife International, 2017. Waterbirds are showing widespread declines, particularly in Asia. [WWW Document]. URL http://www.birdlife.org Accessed 5 March 21

Birdlife International, 2021. Important Bird Areas factsheet: Biebrza river valley. [WWW Document]. URL http://datazone.birdlife.org/site/factsheet/biebrza-river-valley-iba-poland Accessed 22 June 21

Bjornstad ON (2020) ncf: Spatial Covariance Functions. R package version 1.2-9

Brown RD, Mote PW (2009) The response of Northern Hemisphere snow cover to a changing climate. J Clim 22:2124-2145. https://doi.org/10.1175/2008JCLI2665.1

Brzeziński M, Żmihorski M (2009) Nestling diet and parental provisioning behaviour in the Marsh Harrier (circus aeruginosus). Acta Zool Litu 19:93-98. https://doi.org/10.2478/v10043-009-0014-7

Chalmandrier L, Midgley GF, Barnard P, Sirami C (2013) Effects of time since fire on birds in a plant diversity hotspot. Acta Oecologica 49:99-106. https://doi.org/10.1016/j.actao.2013.03.008

Chylarecki P, Chodkiewicz T, Neubauer G, Sikora A, Meissner W, Woźniak B, Wylegała P, Ławicki Ł, Marchowski D, Betleja J, Bzoma S, Cenian Z, Górski A, Korniluk M, Moczarska J, Ochocińska D, Rubacha S, Wieloch M, Zielińska M, Zieliński P, Kuczyński L (2018) Trendy liczebności ptaków w Polsce. Główny Inspektorat Ochrony Środowiska, Warsaw

Čížková H, Květ J, Comín FA, Laiho R, Pokorný J, Pithart D (2013) Actual state of European wetlands and their possible future in the context of global climate change. Aquat Sci 75:3-26. https://doi.org/10. 1007/s00027-011-0233-4

Conway CJ, Nadeau CP, Piest L (2010) Fire helps restore natural disturbance regime to benefit rare and endangered marsh birds endemic to the Colorado River. Ecol Appl 20:2024-2035. https://doi.org/10. 1890/09-1624.1

Curnutt JL, Mayer AL, Brooks TM, Manne L, Bass OL, Fleming DM, Philip Nott M, Pimm SL (1998) Population dynamics of the endangered Cape Sable seaside-sparrow. Anim Conserv 1:11-21. https:// doi.org/10.1111/j.1469-1795.1998.tb00221.x

Davidson NC (2014) How much wetland has the world lost? Long-term and recent trends in global wetland area. Mar Freshw Res 65:934-941. https://doi.org/10.1071/MF14173

De Cáceres M, Legendre P (2009) Associations between species and groups of sites: Indices and statistical inference. Ecology 90:3566-3574. https://doi.org/10.1890/08-1823.1

Dembek W, Oświt J, Rycharski M (2005) Torfowiska i torfy w pradolinie Biebrzy. In: Dyrcz A, Werpachowski C (eds) Przyroda Biebrzańskiego Parku Narodowego. Biebrzański Park Narodowy, OsowiecTwierdza, pp 33-58

Dertien JS, Self S, Ross BE, Barrett K, Baldwin RF (2020) The relationship between biodiversity and wetland cover varies across regions of the conterminous United States. PLoS ONE 15:1-18. https://doi. org/10.1371/journal.pone.0232052

Dixon MJR, Loh J, Davidson NC, Beltrame C, Freeman R, Walpole M (2016) Tracking global change in ecosystem area: the wetland extent trends index. Biol Conserv 193:27-35. https://doi.org/10.1016/j. biocon.2015.10.023

Dudgeon D, Arthington AH, Gessner MO, Kawabata ZI, Knowler DJ, Lévêque C, Naiman RJ, Prieur-Richard AH, Soto D, Stiassny MLJ, Sullivan CA (2006) Freshwater biodiversity: Importance, threats, status and conservation challenges. Biol Rev Camb Philos Soc 81:163-182. https://doi.org/10.1017/S1464 793105006950

Durka M (2020) Wpływ pożaru w Biebrzańskim Parku Narodowym w kwietniu 2020 r . na zmienność wskaźnika NDVI. Jagiellonian University

Filkov A, Leroy-Cancellieri V, Cancellieri D, Gladky D, Simeoni A (2015) Modeling Peat-Fire Hazards: From Drying to Smoldering. In: Prakash A, Rein G (eds) Stracher GB. Coal and Peat Fires A Global Perspective, Amsterdam, pp 89-120

Firth D (1993) Bias Reduction of Maximum Likelihood Estimates. Biometrika 80:27-38

García-Domínguez C, Arévalo JR, Calvo L (2010) Short-term effects of low-intensity prescribed fire on ground-dwelling invertebrates in a Canarian pine forest. For Syst 19:112. https://doi.org/10.5424/fs/ 2010191-01172

Gosper CR, Fox E, Burbidge AH, Craig MD, Douglas TK, Fitzsimons JA, McNee S, Nicholls AO, O'Connor J, Prober SM, Watson DM, Watson SJ, Yates CJ (2019) Multi-century periods since fire in an intact woodland landscape favour bird species declining in an adjacent agricultural region. Biol Conserv 230:82-90. https://doi.org/10.1016/j.biocon.2018.12.011

Gregory RD, Gibbons DW, Donald PF (2004) Bird census and survey techniques. In: Sutherland WJ, Newton I, Green R (eds) Bird Ecology and Conservation: A Handbook of Techniques. OUP, Oxford, pp $17-56$ 
Grillakis MG (2019) Increase in severe and extreme soil moisture droughts for Europe under climate change. Sci Total Environ 660:1245-1255. https://doi.org/10.1016/j.scitotenv.2019.01.001

Grzywaczewski G, Cios S, Sparks TH, Buczek A, Tryjanowski P (2014) Effect of habitat burning on the number of singing males of the aquatic warbler acrocephalus paludicola. Acta Ornithol 49:175-182. https://doi.org/10.3161/173484714X687055

Hanowski JAM, Christian DP, Nelson MC (1999) Response of breeding birds to shearing and burning in wetland brush ecosystems. Wetlands 19:584-593. https://doi.org/10.1007/BF03161696

Hanski I (1999) Habitat connectivity, habitat continuity, and metapopulations in dynamic landscapes. Oikos 87:209-219

Heim RJ, Hölzel N, Heinken T, Kamp J, Thomas A, Darman GF, Smirenski SM, Heim W (2019) Post-burn and long-term fire effects on plants and birds in floodplain wetlands of the Russian Far East. Biodivers Conserv 28:1611-1628. https://doi.org/10.1007/s10531-019-01746-3

Heinze G (2006) A comparative investigation of methods for logistic regression with separated or nearly separated data. Stat Med 25:4216-4226. https://doi.org/10.1002/sim

Heinze G, Ploner M, Jiricka L (2020) logistf: Firth's Bias-Reduced Logistic Regression. R package version 1.24.1

Hochkirch A, Adorf F (2007) Effects of prescribed burning and wildfires on orthoptera in Central European peat bogs. Environ Conserv 34:225-235. https://doi.org/10.1017/S0376892907004006

Hoste-Danyłow A, Romanowski J, Zmihorski M (2010) Effects of management on invertebrates and birds in extensively used grassland of Poland. Agric Ecosyst Environ 139:129-133. https://doi.org/10.1016/j. agee.2010.07.009

Isacch JP, Holz S, Ricci L, Martínez MM (2004) Post-fire vegetation change and bird use of a salt marsh in coastal Argentina. Wetlands 24:235-243. https://doi.org/10.1672/0277-5212(2004)024[0235: PVCABU]2.0.CO;2

Kačergytė I, Arlt D, Berg Å, Żmihorski M, Knape J, Rosin ZM, Pärt T (2021) Evaluating created wetlands for bird diversity and reproductive success. Biol Conserv. https://doi.org/10.1016/j.biocon.2021. 109084

Kania J, Malawska M, Gutry P, Kaminski J, Wilkomirski B (2006) Zmiany przyrodnicze torfowiska niskiego spowodowane pozarem. Woda - Środowisko - Obsz Wiej 06:155-173

Kettridge N, Turetsky MR, Sherwood JH, Thompson DK, Miller CA, Benscoter BW, Flannigan MD, Wotton BM, Waddington JM (2015) Moderate drop in water table increases peatland vulnerability to postfire regime shift. Sci Rep 5:8063. https://doi.org/10.1038/srep08063

Kitowski I, Jakubas D, Mirski P, Pitucha G, Markowska K (2021) Changes in the montagu's harrier circus pygargus diet in Eastern Poland across decades promote insects and reptilians, but not birds and rodents. Ecol Evol. https://doi.org/10.1002/ece3.7416

Korpimäki E, Norrdahl K (1991) Numerical and functional responses of kestrels, short-eared owls, and long-eared owls to vole densities. Ecology 72:814-826

Kotowski W, Piórkowski H (2005) Competition and succession affecting vegetation structure in riparian environments: Implications for nature management. Ecohydrol Hydrobiol 5:51-57

Kotze DC (2013) The effects of fire on wetland structure and functioning. African J Aquat Sci 38:237-247. https://doi.org/10.2989/16085914.2013.828008

Kuczyński L, Chylarecki P (2012) Atlas pospolitych ptaków lęgowych Polski. Bogucki Wydawnictwo Naukowe, Poznań

Lachmann L, Marczakiewicz P, Grzywaczewski G (2010) Protecting Aquatic Warblers (Acrocephalus paludicola) through a landscape-scale solution for the management of fen peat meadows in Poland. In: Isselstein J, Taube F, Auerswald K, Schellberg J, Wachendorf M, Herrmann A, Gierus M, Wrage N, Hopkins A (eds) Schnyder H. Grassland in a Changing World; Grassland Science in Europe. Organising Committee of the 23th General Meeting of the European Grassland Federation and Arbeitsgemeinschaft Grünland und Futterbau der Gesellschaft für Pflanzenbauwissenschaften, Duderstadt pp, pp 711-714

Lesiński G, Romanowski J, Budek S (2016) Winter diet of the long-eared owl Asio otus in various habitats of central and north-eastern Poland. Ann Warsaw Univ Life Sci - SGGW Anim Sci 55(1):81-88

Lüdecke D (2018) ggeffects: Tidy Data Frames of Marginal Effects from Regression Models. J Open Source Softw 3:772

Martin KL, Kirkman LK (2009) Management of ecological thresholds to re-establish disturbance-maintained herbaceous wetlands of the south-eastern USA. J Appl Ecol 46:906-914. https://doi.org/10. 1111/j.1365-2664.2009.01659.x

Martinez Arbizu P (2020) pairwiseAdonis: Pairwise multilevel comparison using adonis. R package version 0.4 
McFadden D (1979) Quantitative methods for analysing travel behaviour ofindividuals: Some recent developments. In: Hensher DA, Stopher PR (eds) Behavioural Travel Modelling. Routledge, London, pp 279-318

Mérô TO, Lontay L, Lengyel S (2015) Habitat management varying in space and time: the effects of grazing and fire management on marshland birds. J Ornithol 156:579-590. https://doi.org/10.1007/ s10336-015-1202-9

Mitchell LR, Gabrey S, Marra PP, Erwin RM (2006) Impacts of marsh management on coastal-marsh bird habitats. Stud Avian Biol 32:155-175

Newman EA, Potts JB, Tingley MW, Vaughn C, Stephens SL (2018) Chaparral bird community responses to prescribed fire and shrub removal in three management seasons. J Appl Ecol 55:1615-1625. https:// doi.org/10.1111/1365-2664.13099

Newton I (2007) Population limitation in birds: The last 100 years. Br Birds 100:518-539

O'Connor RC, Taylor JH, Nippert JB (2020) Browsing and fire decreases dominance of a resprouting shrub in woody encroached grassland. Ecology 101:1-11. https://doi.org/10.1002/ecy.2935

Okruszko T, Duel H, Acreman M, Grygoruk M, Flörke M, Schneider C (2011) Broad-scale ecosystem services of European wetlands-overview of the current situation and future perspectives under different climate and water management scenarios. Hydrol Sci J 56:1501-1517. https://doi.org/10.1080/02626 667.2011 .631188

Oksanen J, Blanchet FG, Friendly M, Kindt R, Legendre P, McGlinn D, Minchin PR, O'Hara RB, Simpson GL Solymos P, Stevens MHH, Szoecs E, Wagner H (2020) vegan: Community Ecology Package

Panzer R (2002) Compatibility of prescribed burning with the conservation of insects in small, isolated prairie reserves. Conserv Biol 16:1296-1307. https://doi.org/10.1046/j.1523-1739.2002.01077.x

Pigot AL, Sheard C, Miller ET, Bregman TP, Freeman BG, Roll U, Seddon N, Trisos CH, Weeks BC, Tobias JA (2020) Macroevolutionary convergence connects morphological form to ecological function in birds. Nat Ecol Evol 4:230-239. https://doi.org/10.1038/s41559-019-1070-4

R Core Team (2013) R: A language and environment for statistical computing.

Ramsar Convention Secretariat (2013) The Ramsar Convention Manual: a guide to the Convention on Wetlands (Ramsar, Iran, 1971), 6th edn. Ramsar Conv Secr Gland, Switzerland

Reid AJ, Carlson AK, Creed IF, Eliason EJ, Gell PA, Johnson PTJ, Kidd KA, MacCormack TJ, Olden JD, Ormerod SJ, Smol JP, Taylor WW, Tockner K, Vermaire JC, Dudgeon D, Cooke SJ (2019) Emerging threats and persistent conservation challenges for freshwater biodiversity. Biol Rev 94:849-873. https://doi.org/10.1111/brv.12480

Rutkowski A, Wiatr A, Wróblewski W (2021) Ochrona przeciwpożarowa [WWW Document]. URL https:// www.biebrza.org.pl/56,ochrona-przeciwpozarowa Accessed 20 November 21

Sharp Bowman TR, McMillan BR, St Clair SB (2017) A comparison of the effects of fire on rodent abundance and diversity in the Great Basin and Mojave Deserts. PLoS ONE 12:20-22. https://doi.org/10. 1371/journal.pone.0187740

Shaw RE, James AI, Tuft K, Legge S, Cary GJ, Peakall R, Banks SC (2021) Unburnt habitat patches are critical for survival and in situ population recovery in a small mammal after fire. J Appl Ecol. https:// doi.org/10.1111/1365-2664.13846

Sikora A, Rohde Z, Gromadzki M, Neubauer G, Chylarecki P (2007) Atlas rozmieszczenia ptaków lęgowych Polski 1985-2004. Bogucki Wydawnictwo Naukowe, Poznań

Sileshi G, Mafongoya PL (2006) The short-term impact of forest fire on soil invertebrates in the miombo. Biodivers Conserv 15:3153-3160. https://doi.org/10.1007/s10531-005-5411-z

Smith EP (2002) BACI Design. In: Piegorsch WW (ed) El-Shaarawi AH. Encyclopedia of Environmetrics, Chichester pp, pp 141-148

Sulwiński M, Mętrak M, Wilk M, Suska-Malawska M (2020) Smouldering fire in a nutrient-limited wetland ecosystem: Long-lasting changes in water and soil chemistry facilitate shrub expansion into a drained burned fen. Sci Total Environ. https://doi.org/10.1016/j.scitotenv.2020.141142

Świętochowski P, Maciorowski G, Henel K, Marczakiewicz P, Grygoruk G (2010) Biebrza River Valley. In: Wilk T, Jujka M, Krogulec J, Chylarecki P (eds) Important Bird Areas of International Importance in Poland. OTOP, Marki, pp 196-198

Szalkiewicz E, Jusik S, Grygoruk M (2018) Status of and perspectives on river restoration in Europe: 310,000 Euros per hectare of restored river. Sustain. https://doi.org/10.3390/su10010129

Szczygieł R, Kwiatkowski M, Kołakowski B (2021) The attempt to assess the fire risk of non-forest terrestrial ecosystems of Biebrza National park - a case study. Folia for Pol 63:167-175. https://doi.org/10. 2478/ffp-2021-0017

Tanneberger F, Bellebaum J, Helmecke A, Minets M (2013) Nesting and foraging characteristics of aquatic warblers acrocephalus paludicola in the fast declining pomeranian population (NE Germany/ NW Poland). Acta Ornithol 48:109-118. https://doi.org/10.3161/000164513X670061 
Turetsky MR, Benscoter B, Page S, Rein G, Werf GRV, Der W, A., (2015) Global vulnerability of peatlands to fire and carbon loss. Nature 8:11-14. https://doi.org/10.1038/ngeo2325

Vieira EM, Briani DC (2013) Short-term effects of fire on small rodents in the Brazilian Cerrado and their relation with feeding habits. Int J Wildl Fire 22:1063-1071. https://doi.org/10.1071/WF12153

Vogl RJ (1973) Effects of fire on the plants and animals of a Florida Wetland. Am Midl Nat 89:334-347

White GC, Bennetts RE (1996) Analysis of frequency count data using the negative binomial distribution. Ecology 77:2549-2557. https://doi.org/10.2307/2265753

Wickham H (2016) ggplot2: Elegant Graphics for Data Analysis. Springer-Verlag, New York

Wilk T, Chodkiewicz T, Sikora A, Chylarecki P, Kuczyński L (2020) Czerwona lista ptaków Polski. OTOP, Marki

Wood SN (2017) Generalized Additive Models: An Introduction with R, 2nd ed Chapman and Hall/CRC

Żmihorski M, Ławicki Ł, Marchowski D, Wylegała P, Pärt T (2016) Spatial variation in long-term trends in a metapopulation of the globally threatened aquatic warbler acrocephalus paludicola in Poland. Acta Ornithol 51:245-256. https://doi.org/10.3161/00016454AO2016.51.2.010

Żmihorski M, Krupiński D, Kotowska D, Knape J, Pärt T, Obłoza P, Berg Å (2018) Habitat characteristics associated with occupancy of declining waders in polish wet grasslands. Agric Ecosyst Environ 251:236-243. https://doi.org/10.1016/j.agee.2017.09.033

Żurek S (2005) Rzeźba i budowa geologiczna Doliny Biebrzy. In: Dyrcz A, Werpachowski C (eds) Przyroda Biebrzańskiego Parku Narodowego. Biebrzański Park Narodowy, Osowiec-Twierdza, pp 19-32

Publisher's Note Springer Nature remains neutral with regard to jurisdictional claims in published maps and institutional affiliations.

\section{Authors and Affiliations}

\section{Michał Walesiak $^{1}$ (D) Grzegorz Mikusiński ${ }^{2,3}$ [ Zbigniew Borowski ${ }^{4}$. Michał Żmihorski ${ }^{1}$}

Grzegorz Mikusiński

grzegorz.mikusinski@slu.se

Zbigniew Borowski

z.borowski@ibles.waw.pl

Michał Żmihorski

zmihorski@ibs.bialowieza.pl

1 Mammal Research Institute, Polish Academy of Sciences, ul. Stoczek 1, 17-230 Białowieża, Poland

2 School for Forest Management, Swedish University of Agricultural Sciences (SLU), Box 43, SE-73921 Skinnskatteberg, Sweden

3 Grimsö Wildlife Research Station, Department of Ecology, Swedish University of Agricultural Sciences (SLU), SE-73091 Riddarhyttan, Sweden

4 Forest Research Institute, Sękocin Stary, Braci Leśnej 3, 05-090 Raszyn, Poland 